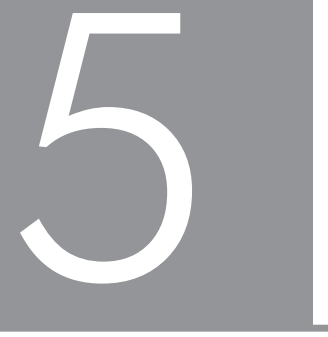

\title{
A SOCIO-CRITICAL MODEL FOR UNDERSTANDING AND PREDICTING POSTGRADUATE STUDENT SUCCESS
}

\section{Paul Prinsloo}

\section{INTRODUCTION}

The increasing massification of higher education and increased access to higher education (Altbach, Reisberg \& Rumbley 2009) are also evidenced in rising doctoral student registration numbers (Altbach 2006). For institutions and individuals alike, the PhD is "the pinnacle" (Altbach 2006:65) of achievement and academic reputation (also see Wolhuter 201 1). Obtaining a doctoral degree is, however, also increasingly taking longer, with average times between six to nine years - depending on the field and institution (Altbach 2006), thus evoking concerns about the dismal attrition rates (Lovelace 2015). Tinto (2014:6) warns that "providing students with access without support [or a reasonable chance of success] is not opportunity". As the time to degree increases, so do the costs (for institution and students alike) and the (uncomfortable) reality of attrition (Altbach 2006; Bitzer, Albertyn, Frick, Grant \& Kelly 2014; Scott 2005; Styger, Van Vuuren \& Heymans 2014).

Concerns about student attrition in postgraduate higher education are well documented and, to a lesser extent, researched (CHE 2009; Gardner 2008, 2009; Herman 2011 ; Koen 2007; Smith, Maroney, Nelson, Abel \& Abel 2006). To a large extent, graduate student retention and attrition remain a "black box" (Ehrenberg, Jakubson, Groen, So \& Price 2007) and a "hidden crisis" (Lovitts \& Nelson 2000). There is no lack of studies focusing on (often) independent variables in postgraduate supervision such as the impact of the quality of supervision (Mackinnon 2004); the competence ecology of supervisors; the research preparedness of postgraduate students and supervisors (Gaff 2002; Greene 2015; Park 2005); the model of delivery (Johnson 2015); the differences in expectations regarding the scope and depth of supervision (Halbert 2015; Halse 2011); the situated-ness and often 
isolation of postgraduate students (Mason 2012); the role of communication and mentorship (Carpenter, Makhadmeh \& Thornton 2015); the role of the department and discipline (Golde 2005); the role of race and gender (Ts'ephe 2014) and various other social and contextual factors (Acker \& Haque 2015; Motshoane \& McKenna 2014; Wolhuter 2011 ). There is also evidence that the scope and nature of knowledge have changed and expanded and that it takes more time to introduce doctoral students to the 'field' (Gopaul 2015).

In contrast to the abundance of models (theoretical and empirical) for understanding and predicting undergraduate student attrition and success in higher education (Prinsloo 2009), there is, as far as I could establish, no attempt to develop a model unique to graduate or doctoral education. Among the possible reasons for this could be the documented gravitas of models developed in the context of undergraduate education such as, but not limited to, the early of models provided by Spady (1970), Tinto (1975), Bean (1990) and Kember (1989). (For an overview, see Braxton 2000; Prinsloo 2009.)

Despite these models, there is a dire lack of evidence on the effectiveness of most strategies to retain students and improve student success (Tinto 2002, 2006). There is also increasing evidence that reasons for student attrition do not, in reverse, explain why students persist, often against many odds. In this regard, Tinto (2006) warns that knowing why students leave does not explain why many students decide to persist, despite many challenges.

This chapter attempts to make a conceptual case for understanding postgraduate student success from a socio-critical perspective as proposed by Subotzky and Prinsloo (2011). Though their model refers to and builds on earlier models of understanding and predicting student success, their social-critical model emphasises student success as a rite of passage shaped by the 'field' (Bourdieu 1987) and nexus of macro-, institutional and personal contexts, habitus and agency. As such the socio-critical model refers to and maps the many intersecting power relations and resulting potential for the student journey to be a site of struggle and contestation. The rite of becoming and being a doctoral candidate therefore embodies student agency as negotiated and negotiating reality amidst contesting rules, disciplinary epistemologies and ontologies (see Barnett 1996; Gopaul 2015).

In this chapter I first present a selection of research on the various factors that have an impact on postgraduate supervision and student success. With this literature review as a basis, I then discuss the socio-critical model (Subotzky \& Prinsloo 2011) and its central constructs before considering the implications of looking at doctoral student success through a socio-critical lens. 


\section{DOCTORAL STUDENT RETENTION AND ATTRITION: A SELECTION OF THE LITERATURE}

Despite the fact that student success, retention and attrition have been studied intensively for a number of decades, resulting in an increased understanding of the multidimensionality and dynamic nature of students' journeys, "most institutions have not yet been able to translate what we know about student retention into forms of action that have led to substantial gains in student persistence and graduation" (Tinto 2006:5). Published research pertaining to graduate and, particularly, doctoral student success refers to and builds on the depth and wealth of conceptual/theoretical and empirical research on factors that have an impact on undergraduate student retention and attrition (eg Lovelace 2015). Recent research in graduate and specifically doctoral student success also emphasises different elements and individual variables such as (but not limited to) the role of the supervisor (Bagaka's, Badillo, Bransteter \& Rispinto 2015) and supervisor identities and trajectories (Maritz \& Prinsloo 2015); the importance of fitting into the epistemological and ontological 'mould' of the graduate school, chosen discipline(s) (Gardner 2008) and epistemologies (Bitzer 2011); the quality of academic input, personal attributes and supervisor and institutional support (Albertyn, Kapp \& Bitzer 2008); student persistence (Kennedy, Terrell \& Lohle 2015); the role of student support (Bolli, Agasisti \& Johnes 2015; Greene 2015); the socio-material conditions of doctoral study (Acker \& Haque 2015); the role of pre-immersion courses for graduate studies (Salani, Albuja \& Azaiza 2016); the role of the research component in postgraduate studies (Bitzer, Albertyn, Van Coller-Peter \& Morrison 2015) and student and supervisor perceptions and expectations regarding the scope of supervision, respective responsibilities and personal and institutional contexts (Heeralal, 2016).

Within this broader context of research on variables that have an impact on postgraduate and more specifically doctoral education, there are relatively few authors (Gopaul 2015) who focus specifically on a socio-critical approach to understanding and predicting doctoral student success. A socio-critical approach to understanding doctoral student success allows one to examine the different, non-linear and mutually constitutive inter- and intra-actions between students, the institution and a range of contexts surrounding these actors as a social space and field, in the Bourdieusian sense (Bourdieu 1987; Chiang 2009; Halse 2011 ).

According to Bourdieu, the field as social space is a 'boundaried site' where players have set and predetermined positions and play according to specific rules: "What players can do, and where they can go during the game, depends on their field position" (Thomson 2008:66). These predetermined field positions, intersecting 
with the state and conditions of/on the field determine what is acceptable and limit options and the state of play. According to Bourdieu, the field, capital and habitus as "an inter-dependent and co-constructed trio" result in an entanglement, a "Gordian knot" (Thomson 2008:67). Thomson (2008:67) emphasises that "there is no level playing ground in a social field; players who begin with particular forms of capital are advantaged at the outset because the field depends on, as well as produces more of, that capital".

Foundational to the socio-critical model is the interplay between habitus, capital and field resulting in a range of constrained agencies for everyone involved, depending on their position on the field. Maton (2008:50) explores, for example, the equation proposed by Bourdieu:

$$
[(\text { habitus })(\text { capital) }]+\text { field }=\text { practice }
$$

The equation illustrates that an individual's habitus functions as both a 'structured and a structuring' presence that interacts with an individual's different forms of capital. The sum of the interplay between habitus and capital has to be considered alongside the state and the position of the individual on the field in order to understand the individual's scope of his or her agency. Maton (2008:51) points out that individual agency or lack thereof is not the result of an individual's habitus but of "relations between one's habitus and one's current circumstances". As Maton suggests, it is crucial that we do not over-estimate the role and impact of habitus and/or capital without taking due cognisance of the logic or 'doxa' of the field in which are located the unwritten "rules of the game" (Maton 2008: 56).

Koen (2007) observes that most of the current explanations for postgraduate student attrition flow from 'structural sociology' perspectives linking attrition to the following: (1) rational-economic; (2) resource-scarcity; (3) ineffective admission policies; (4) schooling deficits; (5) inadequate adaptation; and (6) inappropriate vocation choice (Koen 2007: 14). These six perspectives, however, do not adequately explain questions such as the following:

Why do financially well-off students who performed well at school, whose school subjects and university courses are aligned, and who receive adequate financial support, leave university? Why do students with good marks leave institutions? ... What is the relationship, if any, between academic department and structural university characteristics like planning, organisation, institutional rules, institutional socialization, academic culture and student success of failure? (Koen 2007:17-18).

Despite various correlation studies exploring individual factors or variables, current perspectives leave us with a "unidimensional picture of student departures" (Koen 
2007:18). In an attempt to provide a more complex and nuanced understanding of postgraduate student success and attrition, Koen (2007) proposes that we consider a number of interdependent and often mutually constitutive spheres and their impact on postgraduate student success. The spheres are (1) institutional context; (2) household sphere (encompassing socio-economic group, educational past, domestic obligations, work responsibility, and financial circumstances); (3) personal factors (academic ability, motivation, commitment, desire to finish, and other attributes); (4) organisational factors (appointment policies, financial allocations, departmental structures, intellectual environment, and institutional resources); (5) socio-political influences (the macro socio-political context and higher education regulatory and funding environment); (6) academic performance factors (including part-time versus full-time and faculty affiliation); and (7) research factors (the quality and scope of teaching and supervision in the nexus between student and tuition language, and student attributes).

Gopaul (2015) explores specifically the scope and impact of the rules (written, formal, unwritten and informal) in the field of doctoral education. He proposes doctoral education as a multifaceted field that comprises a variety of stakeholders such as faculty, the providing institution, disciplinary elements and broader labour trends. Doctoral education takes place in the intersection of the different claims by and relations between these different role-players, where the position and capital of the player, the state of the field, and the rules shaping and influencing doctoral education determine hierarchies and agency. Gopaul (2015:86) found that in the context of doctoral education as a site of struggle for legitimacy and autonomy, there is an "ongoing need to examine issues of power, inequality, and value in the various contexts and practices that constitute doctoral study."

The socio-critical conceptual model for understanding student success (Subotzky \& Prinsloo 2011 ) applies the work of Bourdieu (1987), Koen (2007) and others to map the different spheres (Koen 2007) and resulting power relationships (Grenfell 2008; Maton 2008; Thompson 2008) onto the field of student success and retention.

\section{UNDERSTANDING (POSTGRADUATE) STUDENT SUCCESS}

In considering the research on the factors that have an impact on student success, it is crucial to take cognisance of the impact of a variety of contexts such as (1) the geopolitical context (developed vs. developing countries); (2) the theoretical/ philosophical/ideological/disciplinary contexts such as the theoretical, sociological, psychological, comprehensive/ecological, cultural, socio-critical, anthropological and critical-cultural; (3) the institutional context such as distance education or 
residential; and (4) the research methodology as context, for example a causal, path, structural or multinomial logit models (also see Prinsloo 2009).

Acknowledging the rich history of research and different conceptual models explaining student success, Subotzky and Prinsloo (2011) propose that international models are only partially applicable to contexts outside the developed world. In such contexts non-academic factors may have a greater impact on student success than academic factors. Moreover, the combined effects of different combinations of variables at a specific moment in the learning journey are not known. A socio-critical model provides an opportunity to take cognisance of the unique impact of context on our understanding of student success. A socio-critical model also considers the impact of inter-generational, historical structural arrangements and inequalities on students' understanding and enactment of their agency. For example, considering student success in the context of the South African higher education landscape, Subotzky and Prinsloo (2011) state that it is impossible to ignore the inter-generational impact of the educational, epistemological and legislative regimes of colonialism and apartheid on South African society and, specifically, on higher education.

Subotzky and Prinsloo (2011:179) therefore propose that "[f]actors impact on success at three related levels: individual (academic and attitudinal attributes, and other personal characteristics and circumstances), institutional (quality and relevance of academic, non-academic, and administrative services), and suprainstitutional (macro-political and socio-economic factors)" (also see Gopaul 2015; Motshoane \& McKenna 2014). Foundational to the socio-critical model are a number of constructs such as (1) students and institutions as situated agents; (2) the 'student walk' as rite of passage, consisting of mostly non-linear, multidimensional, interdependent interactions at different phases in the nexus between student, institution and broader societal factors; (3) the role and impact of capital and habitus; (4) the different domains and modalities of transformation; and (5) a broad definition of student success.

In the light of the proposition that student success is shaped by a complex, layered, and dynamic set of events, Subotzky and Prinsloo (2011:182) propose that student success "is the outcome of interplay between personal, institutional, and broader contextual factors". In the predominant models there is a clear indication that these models "do not adequately recognize the mutual responsibility in the process" (Subotzky \& Prinsloo 2011:183; emphasis added). While many theoretical and empirical models are based on the extent to which students fit in with the organisational and epistemological culture, Subotzky and Prinsloo (2011) emphasise that is myopic and ineffective. 
Flowing from Bourdieu's (1987) work on habitus, capital and field, a sociocritical understanding of doctoral education therefore needs to consider the following constructs:

Construct 1: Both students and the institution are situated agents. Underlying this construct is the claim that students are not mere passive recipients of services, or customers, but that they make choices, albeit within certain contextual and structural constraints as givens. The same applies to the institution that does not have, contrary to popular opinion, free agency. Higher education institutions are, for example, constrained by funding and regulatory regimes and frameworks.

Construct 2: The student walk. In the nexus between student and institutional agency we find the 'student walk' as "third world" (Barnett 1996:80) or "third space" (Prinsloo, Slade \& Galpin 2012:130) constituted by "[i]nteractions between student and institution [that] are (at least potentially) mutually constitutive" (Subotzky \& Prinsloo 2011 :185). These interactions between students and institution are shaped by a variety of networks both inside and outside the institution and/or the student walk. Subotzky and Prinsloo (2011) suggest that the quality and effectiveness of the 'student walk' are shaped more by non-academic factors than academic factors; by, for instance, mutual knowledge and the extent to which the institution is able to accord with the aspirations and skills/attributes of students, and, vice versa, the extent to which students ' $f i t$ ' in with the institutional culture and disciplinary epistemologies. Where most of the historical models on understanding student success emphasise the 'fit' of students with the institution, Subotzky and Prinsloo (2011) suggest that the responsibility for the 'fit' is shared by both the institution and the students.

Construct 3: The role and shape of capital. "As situated agents, they acquire (or fail to acquire) these various forms of capital partly through the reproductive mechanisms embedded in their socio-economic and cultural contexts and partly through their own individual or institutional/organizational initiatives" (Subotzky \& Prinsloo 2011 :186). It is important to understand that not only are certain forms of capital acknowledged or ignored by higher education, but that the extent and scope of capital students have is not static but dynamic and often specific to both context and discipline.

Construct 4: Habitus. While the role of capital and habitus is well established in research on student success and attrition in higher education, what has not been suggested is that it is not only students' habitus that shape their student walk, but also the institution's habitus and dispositions. 
Construct 5: The domains and modalities of transformation. Students' domains are both inter- and intra-personal while the domains of the institution include academic, social and operational aspects. Three key modalities shape both the students' and the institution's responsiveness, namely attribution, locus of control, and self-efficacy. Once again, while these modalities are well established in the literature on student success and attrition, Subotzky and Prinsloo (2011) propose that they also shape the institution's responsiveness to student needs and aspirations.

Construct 6: A broad definition of success. Subotzky and Prinsloo (2011) suggest that student success is a much wider and much more nuanced phenomenon than the traditionally accepted definitions as determined by regulator and funding frameworks. Student success can imply course success that results in graduation, positive student experiences and high levels of student satisfaction and engagement and/or a successful fit between the graduate and the requirements of civil society, employer expectations and citizenship. Crucial for our understanding of student success in the context of doctoral supervision is the claim by Subotzky and Prinsloo (201 1:188) that success may actually also mean 'not graduating' where, for example, students' life circumstances have changed to such an extent that they feel that they do not need to have a completed qualification.

These six constructs play out in the conceptual model (Figure 5.1) where student success is proposed as the result of mostly non-linear, multidimensional, interdependent interactions at different phases in the nexus between student, institution and broader societal factors. While the visual presentation of the model creates the impression of a linear progression from the left to the right, student success is much more dynamic and definitely, at times, non-linear. External circumstances on both the sides of the student and the institution (number 1) shape student success in often (if not mostly) unpredictable ways, such as sudden unemployment or health problems (on the side of students) or changes in funding frameworks, a national strike or global economic circumstances on the side of the institution. As suggested by Tinto (2014), these shaping conditions are outside the loci of both students and the institution and can have a disproportionate impact on student success. 


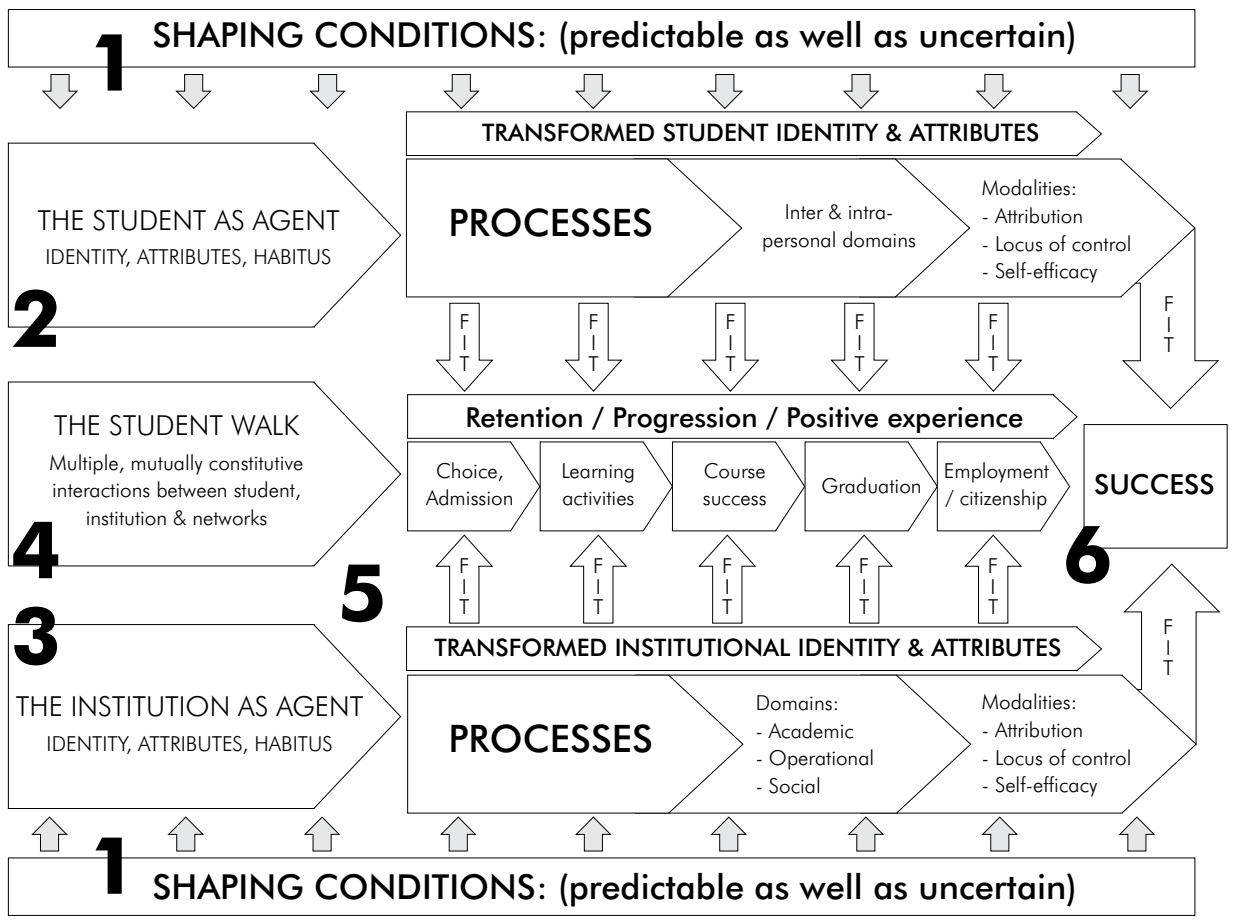

FIGURE 5.1 A social-critical model for understanding student success and retention (Adapted from Subotzky \& Prinsloo 2011)

The respective contexts on the side of the individual and the institution (represented in the diagram by ' 1 ') indicate not only the doxa or the unwritten rules of the game (eg Maton 2008) but also the state of the field. These shaping conditions include those that are predictable and those that are uncertain and unknown. On/in this field, students (represented by '2') and the institution (represented by '3') interact and engage (as indicated by ' 4 ' - the 'student walk') in a series of inter- and intraactions shaped by different steps in the 'student walk' (as represented by '4'): choice/ admission, learning activities, course success, graduation, employment/citizenship. At each step of the 'student walk' the extent to which there is a 'fit' (represented by '5') between students' habitus and capital and the institution's habitus and capital, in the nexus of engagement in a particular doxa, determines the 'success' and progression of students through this process. Student success (as represented by ' 6 ') is therefore the result of mostly non-linear, multidimensional, interdependent interactions at different phases in the nexus between student, institution and broader societal factors. 


\section{IMPLICATIONS OF A SOCIO-CRITICAL MODEL FOR POSTGRADUATE STUDENT SUCCESS AND ATTRITION}

Postgraduate student success is, in many respects, still a "black box" (Ehrenberg et al 2007) as our current research efforts do not seem to explain fully the complexities and entanglement of postgraduate student success. While current research focuses on selected variables within students' habitus and capital, admission and selection criteria, the efficiencies in institutional approval processes, the 'fit' between students and discipline/supervisor, supervisor experience and skills, and so forth, the dynamic interplay between these different variables and role-players/contexts has not yet been seriously considered. As Koen (2007) indicates, current research on postgraduate student success in South African higher education leaves more questions unanswered than we would like to acknowledge.

In light of the socio-critical model (Subotzky \& Prinsloo 2011), of particular concern are the almost inhuman expectations from the institution of supervisors as if supervisors are the most important if not sole actors in ensuring student success. While supervisors' disciplinary knowledge, skills and experience in supervision do play an important role, we cannot and should not negate aspects such as the 'fit' between supervisors and students, the institution as (dis)enabling environment, the (in)efficiency of institutional processes, student:supervisor ratios, and the total workload of supervisors amidst ever increasing teaching and research workloads and pressures.

The supervisor is nothing more but also nothing less than a situated agent with dispositions, capital in a particular field, entangled in institutional processes and personal and macro-contexts. Higher education policy-makers and management need to understand postgraduate supervision as a field in the Bourdieusian sense, where supervisor and student success depends on several distinctive and diverse interactions at different phases in the nexus between student, institution and broader societal factors.

\section{(IN)CONCLUSIONS}

There are many reasons for the dire attrition rates in doctoral education and many research articles focus on one or two dependent or independent variables. An overview of the literature may suggest that the two variables receiving most research attention are the quality (or lack) of supervision, students' (lack of) persistence, and their failure to fit into the processes and epistemologies of institutions, departments and disciplines. Such claims are, however, a severe underestimation of the complexities and multiple interrelationships in the nexus between student, 
institution and macro-societal contexts. A socio-critical model for understanding and predicting doctoral student success provides a map of the many intersecting power relations in the rite of becoming and being a doctoral candidate where student agency is embodied as negotiated and negotiating reality amidst various contesting (and often, incommensurable) rules, disciplinary epistemologies and ontologies.

\section{REFERENCES}

Acker S \& Haque E. 2015. The struggle to make sense of doctoral study. Higher Education Research \& Development, 34(2):229-241.

Albertyn RM, Kapp CA \& Bitzer EM. 2008. Profiling exiting postgraduate students' performance and experiences. South African Journal of Higher Education, 22(4):749-772.

Altbach PG. 2006. Doctoral education: Present realities and future trends. In: JFJ Forest \& PG Altbach. International handbook of higher education. Part 1: Global themes and contemporary challenges. Dordrecht, Netherlands: Springer. 65-79.

Altbach PG, Reisberg L \& Rumbley LE. 2009. Trends in global higher education: Tracking an academic revolution. [Retrieved 29 July 2016 ] http://www.researchgate.net/profile/ Philip_Altbach/publication/225084084_Trends_in_Global_Higher_Education_Tracking_ an_Academic_Revolution/links/551ac40̄20cf251c35b4f5d0d.pdf

Bagaka's JG, Badillo N, Bransteter I \& Rispinto S. 2015. Exploring student success in a doctoral program: The power of mentorship and research engagement. International Journal of Doctoral Studies, 10:323-342.

Bean JP. 1990. Why students leave: Insights from research. In: D Hossler \& JP Bean. The Strategic Management of College Enrolments. San Francisco: Jossey-Bass. 147-169.

Barnett R. 1996. Being and becoming: A student trajectory. International Journal of Lifelong Education, 15(2):72-84.

Bitzer EM. 2011 . Knowledge with wisdom in postgraduate studies and supervision: Epistemological and institutional concerns and challenges. South African Journal of Higher Education, 25(5):855-874.

Bitzer E, Albertyn R, Frick L, Grant B \& Kelly F (eds). 2014. Pushing boundaries in postgraduate supervision. Stellenbosch: African SUN MeDIA.

Bitzer E, Albertyn R, Van Coller-Peter S \& Morrison J. 2015. Aligning student and supervisor perspectives of research challenges. [Retrieved 29 July 2016] http://www0.sun.ac.za/ctl/ wp-content/uploads/2013/02/Dr-Ruth-Albertyn-PROGRESS-REPORT-February-2015.pdf

Bolli T, Agasisti T \& Johnes G. 2015. The impact of institutional student support on graduation rates in US PhD programmes. Education Economics, 23(4):396-418.

Bourdieu P. 1987. What makes a social class? On the theoretical and practical existence of groups. Berkeley Journal of Sociology, 32:1-17.

Braxton JM (ed). 2000. Reworking the student departure puzzle. Nashville: Vanderbilt University Press. 


\section{PART TWO • INSTITUTIONAL MEASURES FOR POSTGRADUATE STUDENT SUCCESS}

Carpenter S, Makhadmeh N \& Thornton LJ. 2015. Mentorship on the doctoral level: An examination of communication faculty mentors' traits and functions. Communication Education, 64(3):366-384.

CHE (Council on Higher Education). 2009. Postgraduate studies in South Africa: A statistical profile. Higher Education Monitor, 7. [Retrieved 29 July 2016 ] http://www.che.ac.za/sites/ default/files/publications/CHE_MonitorProjectV7.pdf

Chiang SY. 2009. Personal power and positional power in a powerful ' $I$ ': A discourse analysis of doctoral dissertation supervision. Discourse \& Communication, 3(3):255-271.

Ehrenberg RG, Jakubson GH, Groen JA, So E \& Price J. 2007. Inside the black box of doctoral education: What program characteristics influence doctoral students' attrition and graduation probabilities? Educational Evaluation and Policy Analysis, 29(2):134-150.

Gaff JG. 2002. Preparing future faculty and doctoral education. Change: The Magazine of Higher Learning, 34(6):63-66.

Gardner SK. 2008. Fitting the mould of graduate school: A qualitative study of socialization in doctoral education. Innovative Higher Education, 33(2): 125-138.

Gardner SK. 2009. Student and faculty attributions of attrition in high and low-completing doctoral programs in the United States. Higher Education, 58(1):97-112.

Golde CM. 2005. The role of the department and discipline in doctoral student attrition: Lessons from four departments. The Journal of Higher Education, 76(6):669-700.

Gopaul B. 2015. Inequality and doctoral education: Exploring the "rules" of doctoral study through Bourdieu's notion of field. Higher Education, 70(1):73-88.

Greene M. 2015. Come hell or high water: Doctoral students' perceptions on support services and persistence. International Journal of Doctoral Studies, 10:501-508.

Grenfell M (ed). 2008. Pierre Bourdieu. Key concepts. 2nd Edition. Durham, UK: Acumen Publishing.

Halbert K. 2015. Students' perceptions of a 'quality' advisory relationship. Quality in Higher Education, 21 (1):26-37.

Halse C. 201 1. 'Becoming a supervisor': The impact of doctoral supervision on supervisors' learning. Studies in Higher Education, 36(5):557-570.

Heeralal PJ. 2016. Improving postgraduate supervision in an Open and Distance Learning (ODL) environment. A case study at the College of Education - University of South Africa (Unisa). South African Journal of Higher Education, 29(3):87-100.

Herman C. 2011 . Obstacles to success - doctoral student attrition in South Africa. Perspectives in Education: The changing face of doctoral education in South Africa: Special Issue 3, 29:40-52.

Johnson C. 2015. Understanding doctoral success factors in online education programs. [Retrieved 29 July 2016] http://scholarworks.waldenu.edu/dissertations/1360/

Kember D. 1989. A longitudinal-process model of dropout from distance education. Journal of Higher Education, 60(3):279-301.

Kennedy DH, Terrell SR \& Lohle M. 2015. A grounded theory of persistence in a limitedresidency doctoral program. The Qualitative Report, 20(3):215-230. 
Koen C. 2007. Postgraduate student retention and success: A South African case study. Cape Town: HSRC Press. [Retrieved 29 July 2016] http://www.hsrcpress.ac.za/product. php? productid $=2205$

Lovelace JM. 2015. Barriers, Motivators, and Perceived Abilities Related to Completion of the Doctoral Degree. Doctoral dissertation. Auburn University. [Retrieved 29 July 2016] https://etd.auburn.edu/handle/10415/5000

Lovitts BE \& Nelson C. 2000. The hidden crisis in graduate education: Attrition from PhD programs. Academe, 86(6):44.

Mackinnon J. 2004. Academic supervision: Seeking metaphors and models for quality. Journal of Further and Higher Education, 28(4):395-405.

Maritz J \& Prinsloo P. 2015. A Bourdieusian perspective on becoming and being a postgraduate supervisor: The role of capital. Higher Education Research \& Development, 34(5):972-985.

Mason MM. 2012. Motivation, satisfaction, and innate psychological needs. International Journal of Doctoral Studies, 7:259-277.

Maton K. 2008. Habitus. In: M Grenfell (ed). Pierre Bourdieu. Key concepts. 2nd Edition. Durham, UK: Acumen Publishing. 48-64.

Motshoane, P \& McKenna S. 2014. More than agency: The multiple mechanisms affecting postgraduate education. In: E Bitzer, R Albertyn, L Frick, B Grant \& F Kelly (eds). Pushing boundaries in postgraduate supervision. Stellenbosch: SUN MeDIA. 185-202.

Park C. 2005. War of attrition: Patterns of non-completion amongst postgraduate research students. Higher Education Review London, 38(1):48-53.

Prinsloo P. 2009. Modelling throughput at Unisa: The key to the successful implementation of ODL. (Working paper). [Retrieved 29 July 2016] http://uir.unisa.ac.za/ handle/10500/6035

Prinsloo P, Slade S \& Galpin F. 2012. Learning analytics: Challenges, paradoxes and opportunities for mega open distance learning institutions. In: Proceedings of the 2 nd International Conference on Learning Analytics and Knowledge. [Retrieved 29 July 2016] http://oro.open.ac.uk/36764/1/p130-prinsloo.pdf

Salani D, Albuja LD \& Azaiza K. 2016. The keys to success in doctoral studies: A preimmersion course. Journal of Professional Nursing. DOI: 10.1016/i.profnurs.2016.01.005 [Retrieved 29 July 2016]. http://www.sciencedirect.com/science/journal/aip/87557223

Scott D. 2005. Retention, completion and progression in tertiary education in New Zealand. Journal of Higher Education Policy and Management, 27(1):3-17.

Smith RL, Maroney K, Nelson KW, Abel AL \& Abel HS. 2006. Doctoral programs: Changing high rates of attrition. The Journal of Humanistic Counselling, Education and Development, 45(1):17-31.

Spady WG. 1970. Dropouts from higher education: An interdisciplinary review and synthesis. Interchange, (1)64-85. DOI: 10.1007/BF02214313. [Retrieved 29 July 2016] http://link. springer.com/article/10.1007/BF02214313 


\section{PART TWO • INSTITUTIONAL MEASURES FOR POSTGRADUATE STUDENT SUCCESS}

Styger A, Van Vuuren G \& Heymans A. 2014. Case study of postgraduate student dropout rate at South African universities. International Business \& Economics Research Journal (IBER), $14(1): 1-14$.

Subotzky G \& Prinsloo P. 2011 . Turning the tide: A socio-critical model and framework for improving student success in open distance learning at the University of South Africa. Distance Education, 32(2): 177-193.

Thomson P. 2008. Field. In: M Grenfell (ed). Pierre Bourdieu. Key concepts. 2nd Edition. Durham, UK: Acumen Publishing. 65-80.

Tinto V. 1975. Dropout from higher education: A theoretical synthesis of recent research. Review of Educational Research, 45:89-125. [Retrieved 29 July 2016] http://www.jstor. org/stable/1 170024

Tinto V. 2002. Promoting student retention: Lessons learned from the United States. Paper presented on 19 June at the 11 th Annual Conference of the European Access Network, Prato, Italy. [Retrieved 29 July 2016] http://survey.csuprojects.org/uploads/wp/79/ wp79euh7GmrceQ2NVV1 I2A/Tinto-re-Access-and-Retention-2002.pdf

Tinto V. 2006. Research and practice of student retention: What next? Journal of College Student Retention, 8:1-19. [Retrieved 29 July 2016] http://csr.sagepub.com/ content $/ 8 / 1 / 1$.refs

Tinto V. 2014 . Tinto's South Africa lectures. Journal of Student Affairs in Africa, 2(2). [Retrieved 29 July 2016] http://www.africanminds.co.za/wp-content/uploads/2015/01/JSAA-Vol-2Issue-2.pdf\# page $=17$

Ts'ephe L. 2014. The experiences of black women undertaking doctoral studies at a South African university. Master's dissertation. Bloemfontein: University of the Free State. [Retrieved 29 July 2016] http://scholar.ufs.ac.za:8080/xmlui/handle/1 1660/760

Wolhuter C. 2011 . Research on doctoral education in South Africa against the silhovette of its meteoric rise in international higher education research. Perspectives in Education: The changing face of doctoral education in South Africa: Special Issue 3, 29:126-138. 